\title{
Comparative study of modeling of Perovskite solar cell with different HTM layers
}

\author{
Abdelhadi SLAMI, Mama BOUCHAOUR and Laarej MERAD \\ University of Tlemcen, Faculty of Sciences, Department of Physics \\ Unité de Recherche «Matériaux et Energies Renouvelables », URMER \\ BP: 119, Fg. Pasteur, Tlemcen, 13000, Algeria
}

\begin{abstract}
The efficiency of $\mathrm{MASnI}_{3}$ based solar cell with various hole transport material (HTM) layers including Spiro-OMeTAD, PEDOT:Pss, and $\mathrm{Cu}_{2} \mathrm{O}$ is studied. Zinc oxide $(\mathrm{ZnO})$ layer is proposed as electron transport layer for lead-free $\mathrm{CH}_{3} \mathrm{NH}_{3} \mathrm{SnI}_{3}$ based Perovskite solar cells. The influence of device parameters such as doping level of the active layer, thickness of the $\mathrm{CH}_{3} \mathrm{NH}_{3} \mathrm{SnI}_{3}$ layer and working temperature is discussed. For optimum parameters of all three structures, efficiency of $24.17 \%, 24.50 \%$, and $25.36 \%$ for PEDOT:Pss, Spiro-OMeTAD, and $\mathrm{Cu}_{2} \mathrm{O}$, respectively is achieved. To study the optimized performance of this Perovskite solar cell, SCAPS-1D software is considered.
\end{abstract}

Keywords: Perovskite, $\mathrm{CH}_{3} \mathrm{NH}_{3} \mathrm{SnI}_{3}$, PEDOT:Pss, Copper oxide, Spiro-OMeTAD, ZnO, HTM, efficiency, SCAPS-1D.

\section{I.INTRODUCTION}

Tn recent years, Perovskite oxides represent a prominent of 1 advanced compounds involved in many areas of science and technology [JTAC 2011 1-3]. Perovskite Solar Cells (PSCs) show a great performance because of their low cost fabrication than traditional solar cells [1]. The yield of PSC increases very rapidly reaching the value of $22 \%$ [2-4]. Owing the multilayer architecture of PSCs, interface has a main role to play in performance and influences long term stability [5]. The $\mathrm{CH}_{3} \mathrm{NH}_{3} \mathbf{S n I}_{3}$ 's absorber layer becomes a suitable alternative of $\mathrm{CH}_{3} \mathrm{NH}_{3} \mathbf{P b I}_{3}$ one because of the toxicity of this typical PSC [6].

The Spiro-OMeTAD HTM is used in organic photovoltaics (OPV) and organic optoelectronics [7], but its causes degradation in the devices performance [8]. Thus, PEDOT:Pss, or $\mathrm{Cu}_{2} \mathrm{O}$ replace the spiro-OMeTAD HTM.
The aim of this paper is to contribute to the optimization of the efficiency of Perovskite solar cell with three different configurations: Glass/FTO/ZnO/ $\mathrm{CH}_{3} \mathrm{NH}_{3} \mathrm{SnI}_{3} / \mathrm{HTM} / \mathrm{Au}$, HTM being Spiro-OMeTAD. 1D solar cell capacitance simulator (SCAPS) is applied for this study.

\section{NUMERICAL MODELLING AND DEVICE SRUCTURE}

II.1. Numerical modeling

To analyze the effect of different electrical parameters on the efficiency of $\mathrm{PCs}, \quad \mathrm{SnO}_{2}: \mathrm{f} / \mathrm{ZnO} / \mathrm{CH}_{3} \mathrm{NH}_{3} \mathrm{SnI}_{3} / \mathrm{Spiro}$ OMeTAD, $\quad \mathrm{SnO}_{2}: \mathrm{f} / \mathrm{ZnO} / \mathrm{CH}_{3} \mathrm{NH}_{3} \mathrm{SnI}_{3} / \mathrm{PEDOT}: \mathrm{Ps}$, and $\mathrm{SnO}_{2}: \mathrm{f} / \mathrm{ZnO} / \mathrm{CH}_{3} \mathrm{NH}_{3} \mathrm{SnI}_{3} / \mathrm{Cu}_{2} \mathrm{O}$ heterojuction-based perovskite solar cell structures, are adopted. SCAPS software is used for simulation. Figure 1, explains the simulation process.

SCAPS is a one dimensional solar cell simulation program developed at the department of Electronics and Information Systems (ELIS) of the University of Gent, Belgium. It allows simulating the behavior of photovoltaic structures. Since that, there are several modifications in this software such as the capability to work with crystalline solar cells (c-Si and GaAs, family) and amorphous cells (a-Si and micro-morphous $\mathrm{Si}$ ) [9]. This simulator has the largest number of AC and DC electrical measurements which can be calculated in dark and light illumination and also at different temperatures. It (SCAPS) solves the Basic semiconductor equations in 1Dimension under steady state condition.

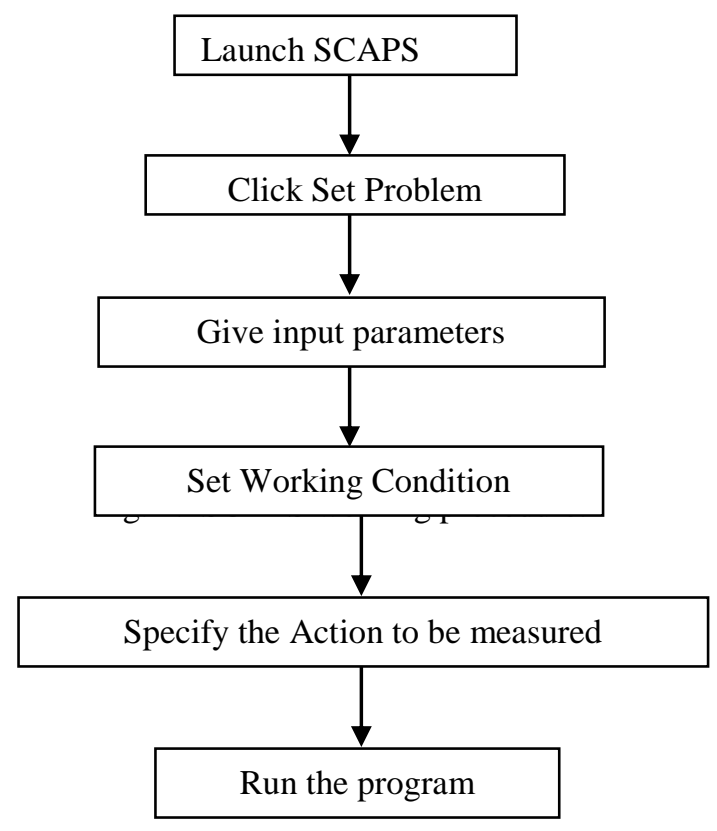

Fig. 1. SCAPS working procedure. 
II.2. Device structure

The cell consists of Methylammonium tin triodide $\left(\mathrm{MASnI}_{3}\right)$; considered as absorber layer. $\mathrm{N}$-type (ZnO-ETM) is arranged at the bottom side, and at the top three p-type (SpiroOMeTAD, PEDOT:Pss and $\mathrm{Cu}_{2} \mathrm{O}$ ) are designed as HTM layer. figure 2 presents the three structures.

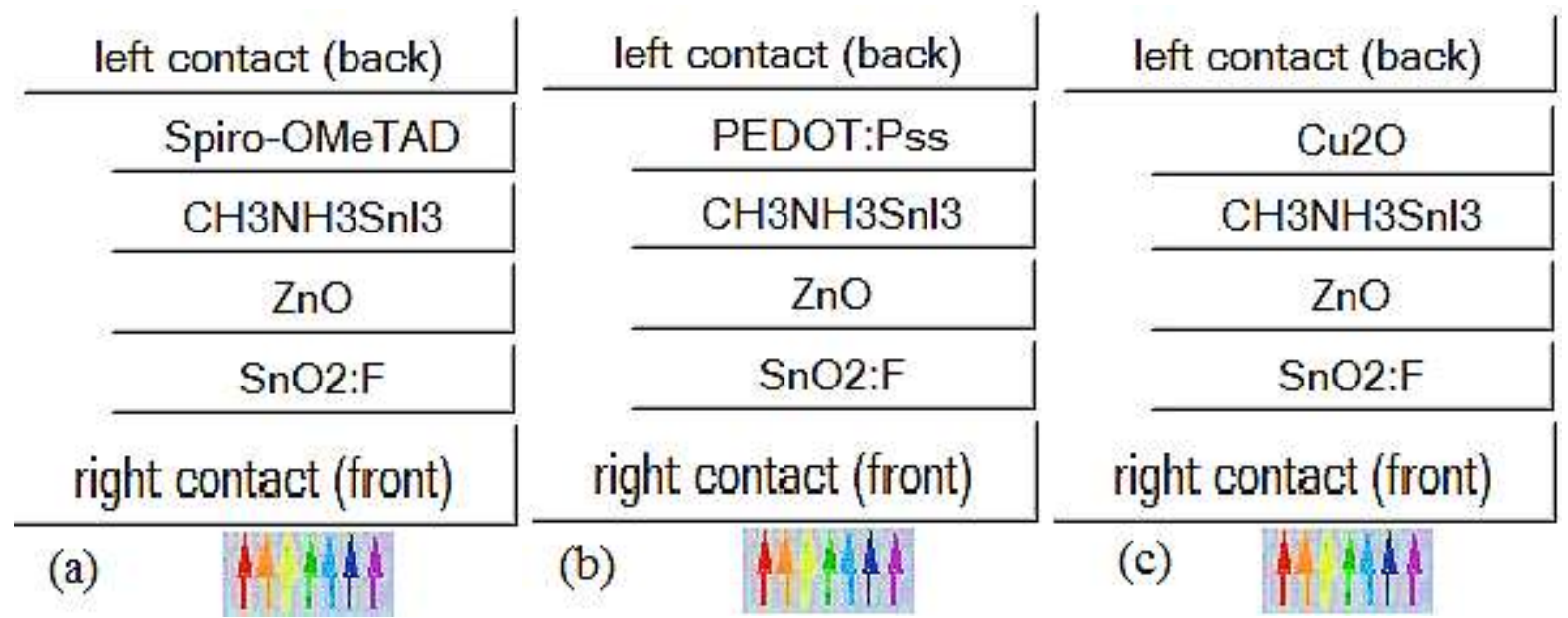

Figure 2:Schematic representation of three architectures with different HTM layers

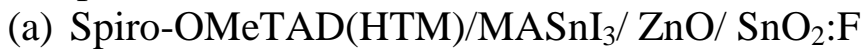

(b) PEDOT:Pss(HTM)/MASnI $3 / \mathrm{ZnO} / \mathrm{SnO}_{2}: \mathrm{F}$

(c) $\mathrm{Cu}_{2} \mathrm{O}(\mathrm{HTM}) / \mathrm{MASnI}_{3} / \mathrm{ZnO} / \mathrm{SnO}_{2}: \mathrm{F}$

To run the simulation, SCAPS needs material parameters; in terms of bandgap (Eg), electron affinity

$(\chi)$, dielectric permittivity $(\varepsilon)$, conduction band density of states $(\mathrm{Nc})$, valence band density of states $(\mathrm{Nv})$,

\begin{tabular}{|c|c|c|c|c|c|c|}
\hline Parameters & $\begin{array}{c}\mathrm{SnO}_{2}: \mathrm{F} \\
{[10,11,12]}\end{array}$ & $\begin{array}{c}\mathrm{ZnO} \\
{[13-15]}\end{array}$ & $\begin{array}{c}\mathrm{CH}_{3} \mathrm{NH}_{3} \mathrm{SnI}_{3} \\
{[16,17-18]}\end{array}$ & $\begin{array}{c}\text { SpiroOMeTAD } \\
{[19-23]}\end{array}$ & $\begin{array}{c}\text { PEDOT :Pss } \\
{[24,25]}\end{array}$ & $\begin{array}{c}\mathrm{Cu}_{2} \mathrm{O} \\
{[22-23]}\end{array}$ \\
\hline Thickness(nm) & 500 & 50 & 900 & 200 & 200 & 200 \\
\hline$E_{g}(e v)$ & 3.5 & 3.2 & 1.3 & 3.17 & 3.6 & 2.17 \\
\hline$\chi(e v)$ & 4 & 4.26 & 4.17 & 2.05 & 1.57 & 3.2 \\
\hline $\boldsymbol{\varepsilon} r$ & 9 & 9 & 8.2 & 3 & 3 & 7.11 \\
\hline$N_{c}\left(\mathrm{~cm}^{-3}\right)$ & $2.20 \times 10^{18}$ & $2.00 \times 10^{18}$ & $1.00 \times 10^{18}$ & $2.20 \times 10^{18}$ & $2.20 \times 10^{17}$ & $2.02 \times 10^{17}$ \\
\hline$N_{v}\left(\mathrm{~cm}^{-3}\right)$ & $1.80 \times 10^{19}$ & $1.80 \times 10^{19}$ & $1.00 \times 10^{18}$ & $1.80 \times 10^{19}$ & $1.80 \times 10^{19}$ & $1.10 \times 10^{19}$ \\
\hline$\mu_{e}\left(\mathrm{~cm}^{2} / \mathrm{Vs}\right)$ & 20 & 200 & 1.60 & $2.00 \times 10^{-4}$ & 10 & 200 \\
\hline$\mu_{h}\left(\mathrm{~cm}^{2} / \mathrm{Vs}\right)$ & 10 & 5 & 1.60 & $2.00 \times 10^{-4}$ & 400 & 80 \\
\hline$N_{D}\left(\mathrm{~cm}^{-3}\right)$ & $2.00 \times 10^{19}$ & $1.50 \times 10^{17}$ & - & - & - & - \\
\hline$N_{A}\left(\mathrm{~cm}^{-3}\right)$ & - & & $1.50 \times 10^{16}$ & $2.00 \times 10^{19}$ & $2.00 \times 10^{19}$ & $2.00 \times 10^{19}$ \\
\hline
\end{tabular}

Table1 : Parameters used for simulation of perovskite solar cell structures using SCAPS-1D

\section{RESULTS AND DISCUSSION}

\section{III.1. Influence of Absorber layer thickness}

The Thickness of $\mathrm{CH}_{3} \mathrm{NH}_{3} \mathrm{SnI}_{3}$ is varied from [50-900] $\mathrm{nm}$ with the three HTM layers (PEDOT:Pss/ $\mathrm{Cu}_{2} \mathrm{O} /$ spiroOMeTAD) and $\mathrm{ZnO}$ as the ETM layer.

The simulated parameters such as Power Conversion Efficiency (PCE), Fill Factor (FF), Short circuit current density (Jsc), open circuit voltage (Voc) of the $\mathrm{CH}_{3} \mathrm{NH}_{3} \mathrm{SnI}_{3}$ solar cells, are shown in Figure 3.

All photovoltaic parameters are maximum at $900 \mathrm{~nm}$. The efficiency increases with increasing thickness. It will be electron mobility $(\mu \mathrm{n})$, hole mobility $(\mu \mathrm{p})$, donor density $\left(\mathrm{N}_{\mathrm{D}}\right)$, acceptor density $\left(\mathrm{N}_{\mathrm{A}}\right)$. Table 1 summarizes data and other theoretical results extracted from published studies.

explained by the increase in generation of electron-hole pairs in the absorber layer. Therefore, the optical density increases. Also, with increasing thickness, the short circuit current $\left(\mathbf{J}_{\mathrm{sc}}\right)$ increases because the thicker absorber layer absorbs more photons, which creates more electron-hole pairs. Moreover, with a thicker absorber layer the chance of recombination increases too; as the charges cross a long distance for diffusion [26]. The results show that the device including $\mathrm{Cu}_{2} \mathrm{O}$ as Hole Transport Material (HTM) has the highest performance. 

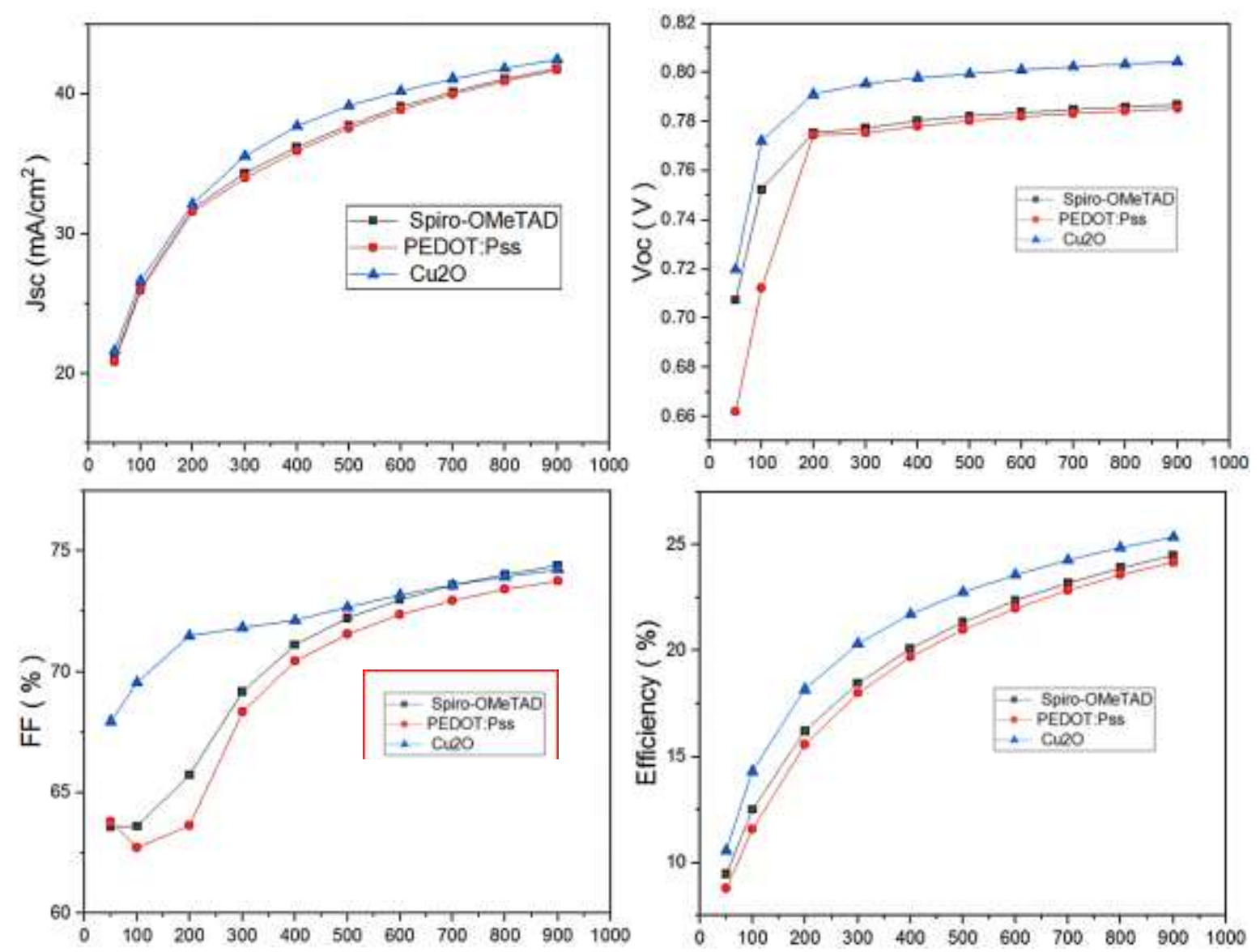

Figure 3: Variation of device performance of absorber thickness layer.

Table 2 recaps all results of PV parameters.

\begin{tabular}{|c|c|c|c|c|}
\hline Perovskite solar cell & Voc $(\mathrm{V})$ & $\mathrm{J}_{\mathrm{sc}}\left(\mathrm{mA} / \mathrm{cm}^{-2}\right)$ & $\mathrm{FF}(\%)$ & PCE $(\%)$ \\
\hline $\mathrm{SnO}_{2}: \mathrm{F} / \mathrm{ZnO} / \mathrm{MASnI}_{3} / \mathrm{PEDOT}: \mathrm{Pss}$ & 0.7853 & 41.72 & 73.77 & 24.17 \\
\hline $\mathrm{SnO}_{2}: \mathrm{F} / \mathrm{ZnO} / \mathrm{MASnI}_{3} / \mathrm{Spiro}_{\mathrm{N}}-\mathrm{OMeTAD}$ & 0.7868 & 41.85 & 74.41 & 24.5 \\
\hline $\mathrm{SnO}_{2}: \mathrm{F} / \mathrm{ZnO} / \mathrm{MASnI}_{3} / \mathrm{Cu}_{2} \mathrm{O}$ & 0.8044 & 42.47 & 74.23 & 25.36 \\
\hline
\end{tabular}

Table 2: Parameters of PSC with different HTM layers.

III.2. Influence of doping of the active layers on the PV parameters

Figure 4, presents the effect of dopant concentration (doping) of Perovskite absorber layer on PV parameters. Acceptor doping concentration $\left(\mathrm{N}_{\mathrm{A}}\right)$ is varying from $10^{15} \mathrm{~cm}^{-3}$ to $10^{17} \mathrm{~cm}^{-3}$. The maximum value appears at $\mathrm{N}_{\mathrm{A}}$ of $1.5 \times 10^{16} \mathrm{~cm}^{-3}$ for both structures with HTM layers (Spiro-OMeTAD, and PEDOT:Pss). On the other hand, for structure with $\mathrm{Cu}_{2} \mathrm{O}$ as HTM layer $\mathrm{N}_{\mathrm{A}}$ is $1.010^{16} \mathrm{~cm}^{-3}$. FF changes also when $\mathrm{N}_{\mathrm{A}}$ is varying. And all structures $\left(\mathrm{SnO}_{2}: \mathrm{f} / \mathrm{ZnO} / \mathrm{CH}_{3} \mathrm{NH}_{3} \mathrm{SnI}_{3} / \mathrm{Spiro}-\right.$ OMeTAD, $\quad \mathrm{SnO}_{2}: \mathrm{f} / \mathrm{ZnO} / \mathrm{CH}_{3} \mathrm{NH}_{3} \mathrm{SnI}_{3} / \mathrm{PEDOT}: \mathrm{Pss}$, and $\mathrm{SnO}_{2}: \mathrm{f} / \mathrm{ZnO} / \mathrm{CH}_{3} \mathrm{NH}_{3} \mathrm{SnI}_{3} / \mathrm{Cu}_{2} \mathrm{O}$ ) reach their maximum values when the $\mathrm{N}_{\mathrm{A}}$ is approximately $1.510^{16} \mathrm{~cm}^{-3}$. Hence, an appropriate doping concentration of the Perovskite absorption layer is favorable to the amelioration of the photo-absorption efficiency, Jsc and FF. However, the Voc drops rapidly when the $\mathrm{N}_{\mathrm{A}}$ exceeds $1.0 \times 10^{16} \mathrm{~cm}^{-3}$ in all three considered models. Its can be explained by Auger recombination rate. Indeed, increasing doping concentration causes higher Auger recombination rate. The enhancement of the electric field is the consequence of the increase of doping concentration. This characteristic favors the separation of carriers and thus the improvement of the cell performance [21].
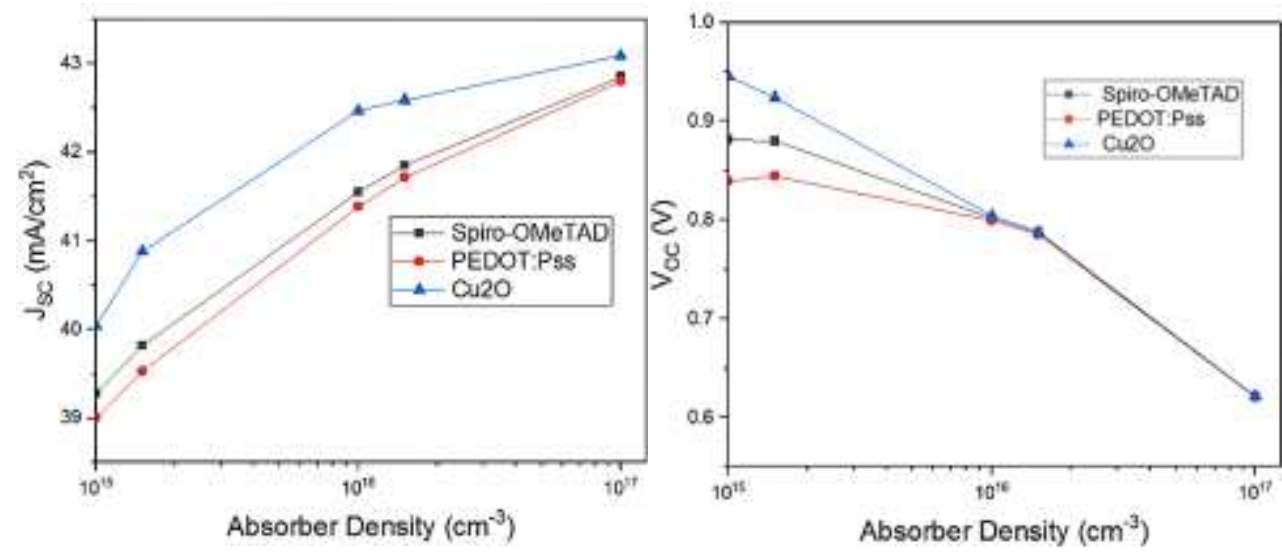

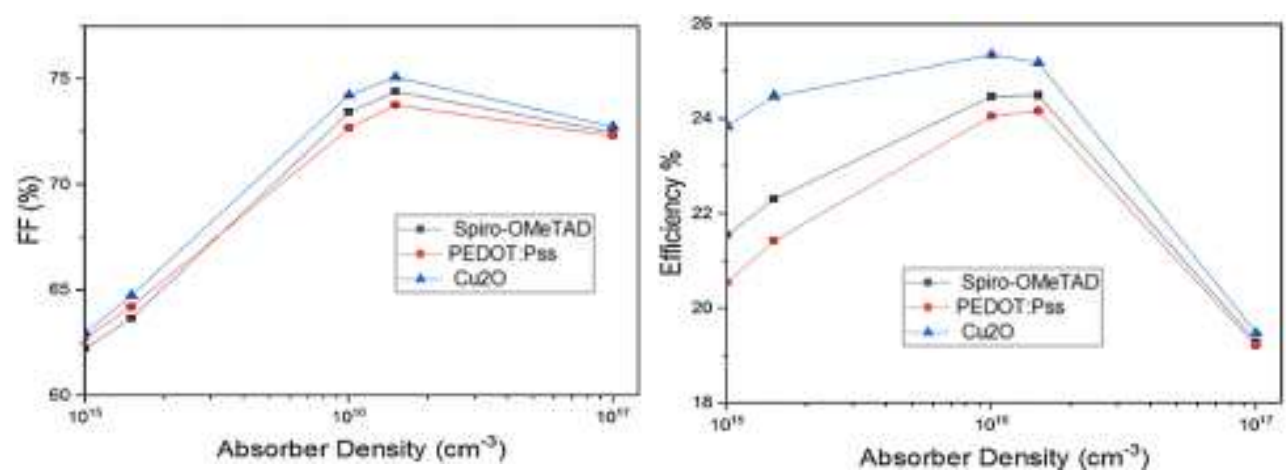

Figure 4: Effect of dopant concentrations of Perovskite absorber layer on PV parameters.

\section{III.3. Influence of temperature}

To understand the effect of temperature on the electrical performance of the solar cell, the temperature of the simulated model is changed from $300 \mathrm{~K}$ to $450 \mathrm{~K}$. Figure 5 shows the variation of PCE versus temperature for all HTM layers. All the three HTM layers simulation models show similar behavior: as the temperature increases the PV parameters are decreasing not shown in this paper.

As the temperature increases, defect density inside the layers increases and then reduces the efficiency. It can be explained by the fact the defect density inside the layers increases with the temperature. It acts on deformation stress [19]. According to figure 5 ; the PSC with $\left(\mathrm{Cu}_{2} \mathrm{O}\right)$ as HTM layer shows the better performance at high temperature $(450 \mathrm{~K})$. Also the PSC with $\left(\mathrm{Cu}_{2} \mathrm{O}\right)$ as HTM layer remains the more better than the two others Spiro-OMeTAD and PEDOT:Pss as HTM layers. The best operating temperature is $300 \mathrm{~K}$. Temperature is an important parameter; it was found that decrease in diffusion length increases of series resistance. By this fill factor and efficiency will be decreased according to papers [26-28].

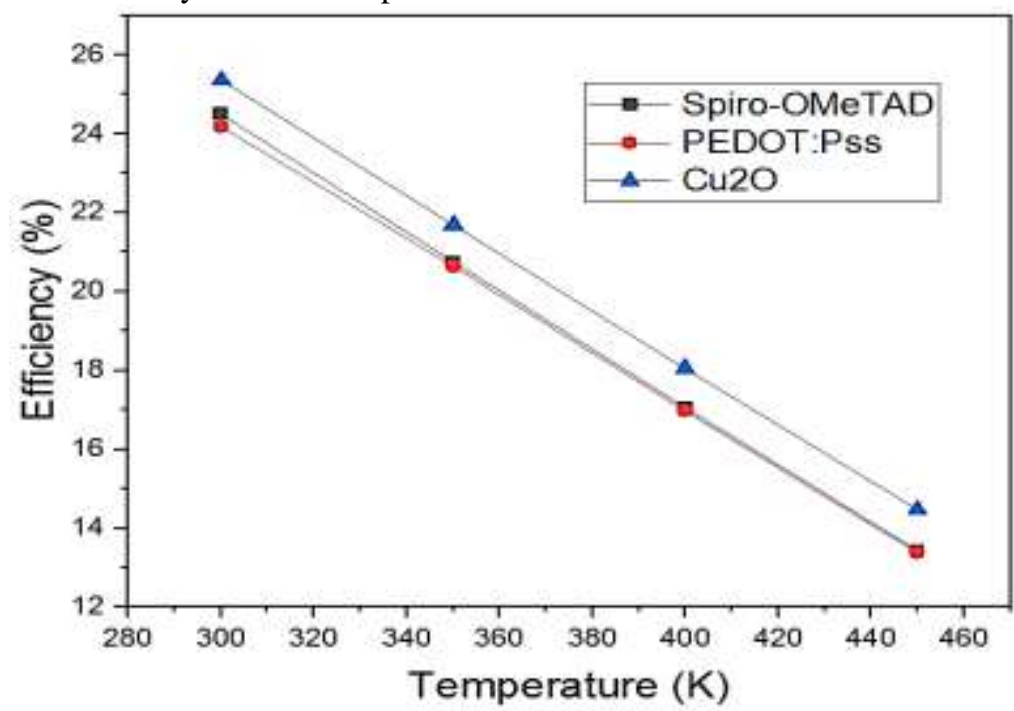

Figure 5: Effect of temperature on the efficiency

\section{IV.CONCLUSION}

In this work $\mathrm{CH}_{3} \mathrm{NH}_{3} \mathrm{SnI}_{3}$ Perovskite solar cell with different parameters was analyzed using SCAPs-1D software device simulation. $\mathrm{ZnO}$ was suggested as electron transport layer (ETL). The performance of of PSC was studied with three different Hole Transport Material (HTM) layers (PEDOT:Pss $/ \mathrm{Cu}_{2} \mathrm{O} /$ spiro-OMeTAD). Thickness, doping and temperature, were varied to study the optimized performance.

\section{REERENCES}

[1] Burgelman, M., Nollet, P. and Degrave, S. (2000) 'Modelling polycrystalline semiconductor s olar cells', Thin Solid Films, 23rd European Photovoltaic Solar Energy Conference, Valencia, Vol. 361, pp. 527-532.

[2] Farhana Anwar and al, "Effect of Different HTM Layers and Electrical Parameters on $\mathrm{ZnO}$ Nanorod-Based Lead Free Perovskite Solar Cell for High-Efficiency Performance" International Journal of Photo energy Volume 2017, Article ID 9846310.

[3] Umari P, Mosconi E and De Angelis F, "Relativistic GW calculations on CH3NH3PbI3 and CH3NH3SnI3 Perovskites for solar cell applications", 2014 Sci. Rep. 44467.

[4] Chen, Q. Y, P.R. huang, T Ma, Cao C He Y, «Electronegativity explanation on the efficiency-enhancing mechanism of the hybrid inorganicorganic Perovskite ABX3 from first-principles study", Chin Phys. B, 2019, 25(2) pp. ISAN4 2R3 TBEA555
Results showed that solar cell containing $\mathrm{Cu}_{2} \mathrm{O}$ as HTM outperform all other devices. A Power conversion efficiency of $25.36 \%$ was obtained. At $300 \mathrm{~K}$ and for a thickness of $900 \mathrm{~nm}$ for $\mathrm{N}_{\mathrm{A}}=1.510^{16} \mathrm{~cm}^{-3}$.

In future, the results of this proposed structure need to be validated through physical fabrication and further studies.

[5] A. Slami, M. Bouchaour and L. Merad, "Numerical Study of Based Perovskite Solar Cells by SCAPS-1D”, International Journal of Energy and Environment Vol. 13, 2019, pp.17-21.

[6] Chong Liu, Jiandong Fan, Hongliang Li, Cuiling Zhang \& Yaohua Mai, "Highly Efficient Perovskite Solar Cells with Substantial Reduction of Lead Content", Scientific Reports, 6:35705.

[7] Hossain, M.I., Alharbi, F.H., Tabet, N., 2015. "Copper oxide as inorganic hole transport material for lead halide Perovskite based solar cells". Sol. Energy 120, 370 - 380.

[8] Nogueira, A. F., Longo, C., \& De Paoli, M.-A. (2004). « Polymers in dye sensitized solar cells: overview and perspectives". Coordination Chemistry Reviews, 248(13-14), 1455-1468.

[9] A. Niemegeers, M. Burgelman, K. Decock, J. Verschraegen, S. Degrave, SCAPS manual, May 2014. 
[10] Kemp K W, Labelle A J, Thon S M, Ip A H, Kramer I J, Hoogland S and Sargent E H "Interface Recombination in Depleted Heterojunction Photovoltaics based on Colloidal Quantum Dots, 2013 Adv. Energy Mater. 3917.

[11] Hao F Stoumpos C C Chang R P H and Kanatzidis M G, "Anomalous Band Gap Behavior in Mixed $\mathrm{Sn}$ and Pb Perovskites Enables Broadening of Absorption Spectrum in Solar Cells", J. Am. Chem. Soc. 2014, 136, 22, pp.8094-8099.

[12] Rutledge SA, Helmy AS. "Carrier mobility esnhancement in poly(3,4ethylenedioxythiophene)-poly (styrenesulfonate) having undergone rapid thermal annealing", Journal of Applied Physics. 2013, 114(13):133708-1-5.

[13] Mihailetchi VD, Van Duren JK, Blom PWM, Hummelen JC, Janssen RAJ, Kroon JM, Rispens MT, Verhees WJH, Wienk MM. "Electron transport in methanofullerene", Advanced Functional Materials. 2003; 13(1), pp. 43-6.

[14] L. Huang, X. Sun, C. Li, R. Xu, J. Xu, Y. Du, Y. Wu, J. Ni, H. Cai, J. Li, Sol. Energy Mater. Sol. Cells 2016, 157, 1038.

[15] S. Bansal, P. Aryal, in 2016 IEEE 43rd Photovolt. Spec. Conf., IEEE, 2016, pp. 747-750.

[16] K. Sobayel, M. Akhtaruzzaman, K. S. Rahman, M. T. Ferdaous, Z. A. Al-Mutairi, H. F. Alharbi, N. H. Alharthi, M. R. Karim, S. Hasmady, N. Amin, "A comprehensive defect study of tungsten disulfide (WS2) as electron transport layer in Perovskite solar cells by numerical simulation", Results Phys. 2019, 12, pp. 1097-1103.

[17] A. Sahu, A. Dixit, "Inverted structure Perovskite solar cells: A theoretical study", Current Appl. Phys. 2018, 18, 1583-1591.

[18] C. Malerba, F. Biccari, C. L. A. Ricardo, M. D'Incau, P. Scardi, A. Mittiga, «Absorption coefficient of bulk and thin film Cu2O », Sol. Energy Mater. Sol. Cells 2011, 95, pp. 2848-2854.

[19] Usha Mandadapu et al "Simulation and Analysis of Lead based Perovskite Solar Cell using SCAPS-1D”, Indian Journal of Science and Technology, Vol 10 (11), 2017.

[21] Hui-Jing $\mathrm{Du}$ and al, «Device simulation of lead-free $\mathrm{CH}_{3} \mathrm{NH}_{3} \mathrm{SnI}_{3}$ perovskite solar cells with high efficiency", 2016 chinese Phys. B 25108802.

[23] NREL Efficiency Chart. This Plot Is Courtesy of the National Renewable Energy Laboratory, Golden, CO.

[25] MH. Kumar, S. Dharani, WL. Leong, PP. Boix, RR. Prabhakar, T. Baikie, C. Shi, H. Ding, R. Ramesh, M. Asta, M. Graetzel, SG. Mhaisalkar,

N. Mathews, "Lead-free halide Perovskite solar cells with high photocurrents", Vol.26, Nº1, pp.712 2-71277.

[26] Fabregat-Santiago, F.; Garcia-Belmonte, G.; Mora-Sero, I.; Bisquert, J. Characterization of Nanostructured Hybrid and Organic Solar Cells by Impedance Spectroscopy. Phys. Chem. Chem. Phys. 2011, 13, 9083-9118.

[27] Bisquert, J.; Fabregat-Santiago, F. Impedance Spectroscopy: A General Introduction and Application to Dye-Sensitized Solar Cells. In DyeSensitized Solar Cells; Kalyanasundaram, K., Ed.; EPFL Press and CRC Press: Lausanne, Switzerland and Boca Raton, FL, 2010.

[28] R. Soni, R. Eva, M. Barea, and F. FabregatSantiago, "Analysis of the Origin of Open Circuit Voltage in Dye Solar Cells" Journal of Physical Chemical Letters, DOI: 10.1021/jz3005464,Vol. 3,No.12, pp 1629- 1634. 